\title{
Protection of the rights of children and adolescents: potential contributions from pediatrics
}

The article by P. García Munitis et al., describes the case of 5 siblings in a clear and unfortunately common situation of violated rights. ${ }^{1}$ The operation of the System for the Comprehensive Protection of the Rights of Children and Adolescents is exemplified, as well as the possible modalities of alternative care implied by a protection measure.

National Law No. 26061, which was enacted several years ago, created this system and provides the legal framework for a paradigm shift in how childhood is conceived, from several decades ago. This new paradigm replaced that of welfare, where "minors" were the subjects of guardianship, and the new concept is that of children as subjects of law. Although the new regulatory frameworks is clearly a necessary condition, it is not enough for the full implementation of proposed changes. Proof of this is that certain terms (e.g., minors advisor) still refer to that past.

This new paradigm is governed by 4 principles:

- the best interest of the child,

- the right to life, survival, and development,

- the right to be heard, and

- the right to family life.

The State therefore acquires a renewed role, the one of guarantor of these rights. ${ }^{2}$

In accordance with such pillars, the guidelines for alternative care suggest that actions aimed at family strengthening should be a priority. Thus, the separation of a child from their family is an exceptional safeguard measure. In those cases, individualized care is recommended so that each child's uniqueness is respected and suited to the fullest. For this reason, among alternative care modes, family care is the first option, because it also allows for the child involvement in community activities. ${ }^{3}$

An alternative to this are care institutions similar to foster homes which, although they provide shelter to a smaller number of children than in the past, in general fail to promote an optimal growth and development. Given the disadvantages posed by living in an institution for the future life of children, the recommendation is that they should stay there for the shortest period possible. $^{3}$
In many regions worldwide, there are no institutional care settings left. In Argentina, the early national reports following the enactment of National Law No. 26061 (from 2011 and 2014) showed that, in spite of the limitations of a crosssectional view in a system that is continually changing, the number of children and adolescents living in non-family institutions reduced by $37 \%$. However, they still account for $83.6 \%$ of all children and adolescents without parental care. In addition, the institutions working in some provinces still practice guardianship methods. ${ }^{4}$

The system has other hurdles, such as the fact that some provinces lack protocols for the implementation of protection measures or that any protection measure used is not recorded. In addition, not all provinces have implemented quality standards regarding care institutions. In some provinces, there are still no family care devices, and 18 out of 24 provinces lack a regulatory framework for this mode of care. ${ }^{5}$

In relation to the stay of children and adolescents in these institutions, the representatives of 19 provinces established that it is usually longer than 180 days, and it is never shorter than 90 days in any province. ${ }^{5}$

Although the purpose of each intervention and measure is to restore rights, a greater effort is required to meet this goal. And although the State is, as mentioned above, a guarantor of such rights, it plays its role via its representatives. Undoubtedly, as pediatricians, we are part of this. Many times, our assessment of a patient allows us to detect a potential violation of rights. In addition, providing care to a child in a socially vulnerable situation entails special characteristics that we should be aware of, as well as the care of those living in a care institution. We also play a role in the assessment and promotion of development, especially in adverse situations, in caregiver training, in the improvement of aspects related to health across the different modes of care, in providing support to foster and adoptive families. ${ }^{6}$ Justice representatives must be aware of the importance of their decisions and that they should be based on the best interest of the child, founded on adequate reasoning and deadlines, and this is also part of our potential responsibilities. 
The relevance of the article mentioned here lies in that it leads us to reconsider and review our knowledge and practice because many of us were professionally trained according to the old paradigm and, in general, received little training in these areas. It discusses childhood situations that many times go unnoticed by society as a whole, even by ourselves.

$$
\begin{array}{r}
\text { María E. Serra* (D) } \\
\text { * Fundación para la Salud Materno Infantil } \\
\text { (FUNDASAMIN), } \\
\text { Autonomous City of Buenos Aires, Argentina. } \\
\text { * Assistant Editor } \\
\text { Archivos Argentinos de Pediatría }
\end{array}
$$

http: / / dx.doi.org/10.5546/ aap.2022.eng.76

To cite: Serra ME. Protection of the rights of children and adolescents: Potential contributions from pediatrics. Arch Argent Pediatr 2022;120(2):76-77.

\section{REFERENCES}

1. García Munitis P, Colombo MV, García Munitis T, García Munitis ME, Ferré MP. Guía para la práctica de acogimiento familiar, relato de una experiencia. Arch Argent Pediatr. 2022; 120(2):140-4.

2. Cisneros A. El niño como sujeto de derechos. In: Serra ME, Soria RM. Manual de prácticas saludables de cuidados en espacios parala primera infancia. Buenos Aires: FUNDASAMIN;2019. [Accessed on: November $\left.22^{\text {nd }}, 2021\right]$. Available at: https: / / www.fundasamin.org.ar/web/manual-de-practicassaludables-de-cuidado-en-espacios-para-la-primerainfancia/

3. RELAF, UNICEF. Guía de estándares para el personal de las entidades públicas y privadas que seocupan dela protección de derechos de niñas, niños y adolescentes. Aplicación de las directrices de las Naciones Unidas sobre las modalidades alternativas de cuidado de los niños. Buenos Aires; abril 2011. [Accessed on: November 22nd, 2021]. Available at: https: / / www.relaf.org/Directrices_VA.pdf

4. Segade A. Reflexión sobre el Sistema de Protección Integral de los derechos de niños, niñas y adolescentes. Deudas y desafíos. Marzo 2018. [Accessed on: November $22^{\text {nd }}, 2021$ ]. Available at: https: / / doncel.org.ar/2018/03/12/14254/

5. UNICEF, SENNAF, Ministerio de Salud y Desarrollo Social de la Nación Argentina. Situación de niñas, niños y adolescentes sin cuidados parentales en la República Argentina. Relevamiento nacional. Actualización 2017. Noviembre 2018. [Accessed on: November 22 ${ }^{\text {nd }}, 2021$ ] Available at: https://www.unicef.org/argentina / informes / situación-de-niños-niñas-y-adolescentes-sincuidados-parentales-en-argentina-0

6. American Academy of Pediatrics. Committee on Early Childhood and Adoption and Dependent Care. Developmental issues for young children in foster care. Pediatrics. 2000;106(5):1145-50. 